\title{
Neurological Effect of Lead Exposure in Children
}

Hassan $\mathrm{MS}^{1}$, Patwary MKK ${ }^{2}$, Rahman $\mathrm{MM}^{3}$, Sonia $\mathrm{SF}^{4}$, Kabiruzzaman $\mathrm{M}^{5}$, Alim $\mathrm{MA}^{6}$, Salahuddin $\mathrm{AJM}^{7}$, Zahid $\mathrm{RI}^{8}$, Ara $\mathrm{F}^{9}$, Eusuf $\mathrm{NM}^{10}$, Sultana $\mathrm{S}^{11}$, Haque $\mathrm{A}^{12}$

\begin{abstract}
Lead poisoning is one of the burning issues in Bangladesh. This study assessed the relation of blood lead level with $I Q$ and peripheral nerve function in environmental lead exposed primary school childrenin Dhaka.

Blood lead level (BLL) was measured in 84 primary school children in an urban industrial area of Dhaka. IQ was measured with Wechsler Intelligence Scales- Revised for children. Electrophysiological evaluation was done in 31 children.

Verbal, Performance and Full scale IQ had a negative correlation with blood lead level $(p<0.001)$. Decrement in Verbal, Performance and Full scale IQ associated with $I$ microgram per deciliter increase in blood lead level were $0.99,0.86$ and 0.95 respectively $(p<0.001)$. None had clinical features of neuropathy. Statistical analysis also did not show any significant difference in NCS between children with normal and elevated BLL ( $p$ value $>0.05$ ).

It was found that IQ of children decreased in a linear trend with increasing blood lead level. This study did not find any clinical or electrophysiological evidence of peripheral nerve dysfunction in the environmental lead exposed children.
\end{abstract}

Key words:IQ, neuropathy, lead exposure, children
1. Mohammad Sayeed Hassan MBBS, FCPS, MD
Medical Officer, National Institute of Neurosciences, Dhaka
2. Corresponding Authors: Md. Khairul Kabir Patwary
Medical Officer, National Institute of Neurosciences, Dhaka
3. Md. Mahbubur Rahman
Medical Officer, Shahid Zia Medical College, Bogra
4. Sheikh Farjana Sonia MD (Pediatrics) Student
Bangladesh Institute of Child Health, Dhaka
5. Md. Kabiruzzaman
Medical Officer, National Institute of Neurosciences, Dhaka
6. Md. Abdul Alim
Medical Officer, National Institute of Neurosciences, Dhaka
7. Abu Jafor Md. Salahuddin
Registrar, National Institute of Neurosciences, Dhaka
8. Rashed Imam Zahid
Medical Officer, National Institute of Neurosciences, Dhaka
9. Ferdous Ara
Assistant Registrar, National Institute of Neurosciences, Dhaka
10. Nuruddin Md Eusuf
Medical Officer, National Institute of Neurosciences, Dhaka
11. Shakila Sultana
Resident, Department of Paediatrics
Bangabandhu Sheikh Mujib Medical University, Dhaka
12. Anisul Haque
Professor, Department of Neurology
Bangabandhu Sheikh Mujib Medical University, Dhaka

\section{Introduction}

Dhaka, Bangladesh, was discovered to have one of the highest air lead level in the world ${ }^{1}$. Almost $90 \%$ of the children has elevated blood lead level (BLL) in Dhaka² BLL at the urban industrial area of Bangladesh is significantly higher than those at the rural and urban nonindustrial areas $^{3}$. Diagnosis of lead exposure is based on blood lead level measured in micrograms of lead per deciliter of blood $(\mu \mathrm{gm} / \mathrm{dl})$. World Health Organization (WHO) states that BLL of $10 \mu \mathrm{gm} / \mathrm{dl}$ or above is abnormal ${ }^{4}$. The purpose of this study was to asses IQ and peripheral nerve function in children of urban industrial area of Dhaka to evaluate the neurological effect of environmental lead exposure.

Lead poisoning can occur from both occupational and environmental source ${ }^{5}$. Lead is toxic to many organs and tissues including nervous systems ${ }^{6}$. Lead is much more harmful to children than adults because it can affect children's developing nerves and brains ${ }^{7}$. Peripheral nervous system (PNS) effects are more prominent in adults and central nervous system (CNS) effects are more prominent in children ${ }^{8}$.While heavy exposure to inorganic lead is capable of inducing symptomatic neuropathy, subclinical neuropathy is more common ${ }^{9-12}$. This study assessed the relationship of blood lead level with IQ for CNS effect and peripheral nerve function for PNS effect in lead exposed children.

An intelligence quotient (IQ) is a score derived from one of several different standardized tests designed to assess intelligence. The scoring of modern IQ tests such as the Wechsler Intelligence Scale is now based on standard scoring of the subject's rank order on the test item content with the median score set to 100 , and a standard deviation of 15 . The effect of lead on children's cognitive abilities takes place at very low levels ${ }^{13}$. Between the blood lead levels of 5 and $35 \mu \mathrm{gm} / \mathrm{dl}$, an IQ decrease of 2-4 points for each $\mu \mathrm{g} / \mathrm{dL}$ increase is reported in children.

The six East Asian nations all have IQ in the range between 105 and 108. The 29 European nations all have IQs in the range between 92 and 102. The 19 nations of sub-Saharan Africa all have IQ in the range between 59 and 73. The average estimated national IQ of Bangladesh is 81 and measured national IQ of India is 81. In Bangladesh, 10 year old children showed their mean Full scale IQ, Verbal IQ and Performance IQ were $64 \pm 11.6,70.8 \pm 12.2,63.9 \pm 11.9$ respectively ${ }^{14}$. 


\section{Materials and Methods}

The study was conducted from January 2009 to December 2010 in BSMMU. Study population was selected from a primary school, where the tannery industries of Dhaka are located. Blood lead level (BLL) was measured in 84 children of 6 to 12 years age. Patients suffering from diabetes mellitus, hypothyroidism, speech and hearing abnormalities, children with family history of peripheral neuropathy were excluded from the study. IQ levels were measured in 84 children. 31 children agreed to do electrophysiological evaluation. Denial of consent to perform NCS was the primary reason for not performing the test.

BLL was measured by using a portable Lead Care instrument (ESA Inc, Chelmsford, MA, USA) from venous blood $(0.5 \mathrm{ml})$. The instrument has been approved by the US Food and Drug Administration (FDA), and is being used in many health centers in the United States.

IQ levels were measured by psychologist, well trained in this field with the use of Wechsler Intelligence Scales for Children -Revised (WISC-R) suitable for children $\geq 6$ years of age. WISC-R consisted of five verbal subtests which together provided a verbal IQ score and a similar number of performance subtests that together provided a performance IQ score. The subtests were administered in standardized environments according to standardized procedures. Summation of these weighted items across verbal, performance and full scale raw scores were done and then transformed these into measures of estimated verbal, performance, and full scale IQ, using procedures presented in the test manual.

Nerve conduction studies were performed by a single neurophysiologist by NIHON KOHDON (Neuropack E) machine. Sensory nerve action potentials were recorded using an antidromic stimulus. Surface electrodes were used for recording and for stimulation. NCS was done in cross limb (right upper and left lower limb).

All data was recorded systematically in preformed data collection form and quantitative data was expressed as mean and standard deviation. Statistical analyses of the results were obtained by using window based computer software devised with Statistical Packages for Social Sciences (SPSS16). Statistical tests for significance of difference were done using student's t test. Multiple logistic regression analysis was done to evaluate the risk factors.ANOVA and then perform Bonferroni test for comparison between two groups.

\section{Results}

The current study was conducted in 84 primary school children of 6 to 12 years age. BLL range was 3.6 to 31.9 $\mu \mathrm{gm} / \mathrm{dl}$ with mean BLL of $15.33 \pm 3.54 .52$ were boys with mean BLL of $15.45 \pm 3.67 .32$ were girls with mean BLL of $15.15 \pm 3.38$. Of the 84 children, $78(92.8 \%)$ had elevated $\operatorname{BLL}(\geq 10 \mu \mathrm{gm} / \mathrm{dl})$.
Mean $( \pm \mathrm{SD})$ of verbal IQ among children with blood lead level of $\leq 10,10-20$, and $>20$ micro gm /dl was $83.00 \pm$ $9.10,73.62 \pm 5.82$, and $65.40 \pm 4.35$ respectively.Mean $( \pm$ SD) of performance IQ among children with blood lead level of $\leq 10,10-20$ and $>20$ micro gm /dl was $78.67 \pm 7.94$, $71.34 \pm 6.13$, and $67.20 \pm 4.9667 .20 \pm 4.96$ respectively. Mean $( \pm$ SD) of full scale IQ among children with blood lead level of $\leq 10,10-20$ and $>20$ micro gm /dl was 78.50 $\pm 6.06,70.01 \pm 3.97$, and $63.30 \pm 2.67$ respectively.

Statistical test was done by ANOVA and then perform Bonferroni test for comparison between two groups. This shows statistically significant difference of verbal IQ, performance IQ and full scale IQ with blood lead levelbetween the groups ( $\mathrm{p}=0.001)$ shown in Table 1 .

Table 1: statistical analysis between the groups showing p values

\begin{tabular}{llll}
\hline & p value & & \\
\hline BLL (UGM/d) & $\begin{array}{l}\text { Verbal } \\
\text { IQ }\end{array}$ & $\begin{array}{l}\text { Performace } \\
\text { IQ }\end{array}$ & $\begin{array}{l}\text { Full } \\
\text { scale }\end{array}$ \\
\hline$<10$ vs. $10-20$ vs. $>20$ & 0.001 & 0.002 & 0.001 \\
$<10$ vs. $10-20$ & 0.001 & 0.019 & 0.001 \\
$<10$ vs. $>20$ & 0.001 & 0.002 & 0.001 \\
$10-20$ vs. $>20$ & 0.001 & 0.15 & 0.001 \\
\hline
\end{tabular}

In this study, it was found that IQ of children decreased in a linear trend with increasing blood lead level. After adjustment for sex, $\mathrm{Hb} \%$, family monthly income, occupation of father and mother, educational level of father and motherVerbal, Performance and Full scale IQ had a negative correlation with blood lead level $(\mathrm{p}<0.001)$ shown in table 2. Decrement inVerbal, Performance and Full scale IQ associated with 1 microgram per deciliter increase in blood lead level was $0.99,0.86$ and 0.95 respectively $(\mathrm{p}<0.001)$.

Table 2: Correlations of verbal, performance and full scale IQ with blood lead level

\begin{tabular}{lcc}
\hline Blood lead level vs & r value & p value \\
\hline Verbal IQ & -0.558 & $<0.001$ \\
Performance IQ & -0.544 & $<0.001$ \\
Full scale IQ & -0.738 & $<0.001$ \\
\hline
\end{tabular}

Clinical evaluation for evidence of peripheral neuropathy was done in 84 students. Symptoms related to peripheral nerve dysfunction were found in none of the subject. Clinical signs of peripheral neuropathy were also absent in all the children.Nerve function recordings were within normal level in all groups of students. Statistical analysis also did not find any significant difference in NCS between the children with normal and elevated BLL. The results are shown in table 3 and table 4. 
Table 3- Comparison of mean $( \pm$ SD) motor NCS between normal and elevated BLL group $(\mathrm{NS}=$ not significant, $\mathrm{ms}=$ milisecond, $\mathrm{mv}=$ milivolt, $\mathrm{m} / \mathrm{s}=$ meter $/$ second)

\begin{tabular}{|c|c|c|c|c|c|c|c|c|c|}
\hline \multirow{2}{*}{$\begin{array}{l}\text { Name of } \\
\text { nerve }\end{array}$} & \multirow{2}{*}{$\begin{array}{l}\text { Distal } \\
\text { BLL } \\
<10 \\
\mu \mathrm{gm} / \mathrm{dl}\end{array}$} & \multicolumn{2}{|c|}{ Motor latency (ms) } & \multicolumn{3}{|c|}{ Motor amplitude (mv) } & \multicolumn{3}{|c|}{ Motor conduction velocity $(\mathrm{m} / \mathrm{s})$} \\
\hline & & $\begin{array}{l}\text { BLL } \\
\geq 10 \\
\mu \mathrm{gm} / \mathrm{dl}\end{array}$ & $\begin{array}{l}P \\
\text { value }\end{array}$ & $\begin{array}{l}\text { BLL } \\
<10 \\
\mu \mathrm{gm} / \text { dl }\end{array}$ & $\begin{array}{l}\text { BLL } \\
<10 \\
\mu g m / \text { dl }\end{array}$ & $\begin{array}{l}\mathbf{P} \\
\text { value }\end{array}$ & $\begin{array}{l}\text { BLL } \\
\geq 10 \\
\mu \mathrm{gm} / \mathrm{dl}\end{array}$ & $\begin{array}{l}\text { BLL } \\
\geq 10 \\
\mu \mathrm{gm} / \mathrm{dl}\end{array}$ & $\begin{array}{l}P \\
\text { value }\end{array}$ \\
\hline Median & $\begin{array}{l}2.77 \\
(0.24)\end{array}$ & $\begin{array}{l}2.87 \\
(0.41)\end{array}$ & $0.251 \mathrm{NS}$ & $\begin{array}{l}13.50 \\
(4.02)\end{array}$ & $\begin{array}{l}13.76 \\
(4.50)\end{array}$ & $0.550 \mathrm{NS}$ & $\begin{array}{l}60.23 \\
(6.53)\end{array}$ & $\begin{array}{l}60.93 \\
(5.75)\end{array}$ & $0.712 \mathrm{NS}$ \\
\hline Ulnar & $\begin{array}{l}1.89 \\
(0.29)\end{array}$ & $\begin{array}{l}2.14 \\
(0.38)\end{array}$ & $0.249 \mathrm{NS}$ & $\begin{array}{l}7.47 \\
(1.37)\end{array}$ & $\begin{array}{l}8.25 \\
(1.86)\end{array}$ & $0.201 \mathrm{NS}$ & $\begin{array}{c}60.56 \\
(5.53)\end{array}$ & $\begin{array}{l}60.08 \\
(7.79)\end{array}$ & $0.290 \mathrm{NS}$ \\
\hline Tibial & $\begin{array}{l}3.00 \\
(0.22)\end{array}$ & $\begin{array}{l}2.92 \\
(0.29)\end{array}$ & $0.330 \mathrm{NS}$ & $\begin{array}{l}19.91 \\
(4.93)\end{array}$ & $\begin{array}{l}17.87 \\
(4.66)\end{array}$ & $0.962 \mathrm{NS}$ & $\begin{array}{l}51.29 \\
(4.04)\end{array}$ & $\begin{array}{l}49.76 \\
(4.08)\end{array}$ & $0.935 \mathrm{NS}$ \\
\hline Peroneal & $\begin{array}{l}3.74 \\
(0.73)\end{array}$ & $\begin{array}{l}3.64 \\
(0.76)\end{array}$ & $0.686 \mathrm{NS}$ & $\begin{array}{l}4.69 \\
(1.78)\end{array}$ & $\begin{array}{l}4.81 \\
(1.69)\end{array}$ & $0.808 \mathrm{NS}$ & $\begin{array}{l}58.44 \\
(9.05)\end{array}$ & $\begin{array}{l}52.98 \\
(7.67)\end{array}$ & $0.559 \mathrm{NS}$ \\
\hline
\end{tabular}

Table 4- Comparison of mean $( \pm$ SD) sensory NCS between normal and elevated BLL group $(\mathrm{NS}=$ not significant, ms = mili second, $\mu \mathrm{v}=$ micro volt, $\mathrm{m} / \mathrm{s}=$ meter/ second)

\begin{tabular}{|c|c|c|c|c|c|c|c|c|c|}
\hline \multirow{2}{*}{$\begin{array}{l}\text { Name of } \\
\text { nerve }\end{array}$} & \multicolumn{3}{|c|}{ Sensory latency (ms) } & \multicolumn{3}{|c|}{ Sensory amplitude $(\mu v)$} & \multicolumn{3}{|c|}{ Sensory conduction velocity $(\mathrm{m} / \mathrm{s})$} \\
\hline & $\begin{array}{l}\text { BLL } \\
<10 \\
\mu \mathrm{gm} / \mathrm{dl}\end{array}$ & $\begin{array}{l}\text { BLL } \\
\geq 10 \\
\mu \mathrm{gm} / \mathrm{dl}\end{array}$ & $\begin{array}{l}P \\
\text { value }\end{array}$ & $\begin{array}{l}\text { BLL } \\
<10 \\
\mu \mathrm{gm} / \mathrm{dl}\end{array}$ & $\begin{array}{l}\text { BLL } \\
<10 \\
\mu \mathrm{gm} / \mathrm{dl}\end{array}$ & $\begin{array}{l}P \\
\text { value }\end{array}$ & $\begin{array}{l}\text { BLL } \\
\geq 10 \\
\mu \mathrm{gm} / \mathrm{dl}\end{array}$ & $\begin{array}{l}\text { BLL } \\
\geq 10 \\
\mu \mathrm{gm} / \mathrm{dl}\end{array}$ & $\begin{array}{l}P \\
\text { value }\end{array}$ \\
\hline Median & $1.97(0.19)$ & $2.03(0.22)$ & $0.458 \mathrm{NS}$ & $32.42(7.63)$ & $31.42(8.35)$ & $0.890 \mathrm{NS}$ & $57.44(8.89)$ & $55.83(7.86)$ & $0.519 \mathrm{NS}$ \\
\hline Ulnar & $1.70(0.20)$ & $1.70(0.22)$ & $0.585 \mathrm{NS}$ & $30.57(7.46)$ & $29.46(7.82)$ & $0.473 \mathrm{NS}$ & $58.77(2.53)$ & $56.70(5.86)$ & $0.602 \mathrm{NS}$ \\
\hline Sural & $1.88(0.16)$ & $1.84(0.21)$ & $0.187 \mathrm{NS}$ & $34.43(6.48)$ & $32.66(8.59)$ & $0.458 \mathrm{NS}$ & $54.37(3.30)$ & $53.36(3.19)$ & $0.708 \mathrm{NS}$ \\
\hline
\end{tabular}

\section{Discussion}

IQ was measured over eighty four children. The mean BLL of 84 students was $15.33 \pm 3.54 \mu \mathrm{gm} / \mathrm{dl}$; boys had $15.45 \pm$ $3.67 \mu \mathrm{gm} / \mathrm{dl}$, and girls had $15.15 \pm 3.38 \mu \mathrm{gm} / \mathrm{dl}$. In a study by Lanphear(2005) $)^{15}$ showed blood lead level varied by gender, educational level of parents, poverty index ratio and race; mean BLL was higher for males than females and varied inversely with poverty index ratio and educational level of parents. In present study BLL was high in boys, in income group $<5000 \mathrm{Tk} / \mathrm{month}$, in group of mothers with upto primary education, in group of fathers with upto primary education and in group of mothers with occupation of service including garments worker.

Mean verbal IQ, performance and full scale IQ was $73.31 \pm 6.98, \quad 71.31 \pm 6.54, \quad 69.82 \pm 53 \quad$ respectively. Wasserman (2005) ${ }^{14}$ studied on 142 children 10 years old, in Araihazar, Bangladesh showed their mean Full scale IQ, Verbal IQ, and Performance IQ were $64 \pm 11.6,70.8 \pm 12.2$ and $63.9 \pm 11.9$ respectively. In the current study, it was found that IQ of children decreased in a linear trend with increasing blood lead level, which is consistent with previous studies (Lanphear, 2005; National Research Council, 1993; Schwartz, 1994; Pocock. 1994; Chen, 2005; Herbert, 1990) $)^{15-20}$.

After adjustment for sex, $\mathrm{Hb} \%$, monthly income, occupation of father, occupation of mother, educational level of father, educational level of mother, verbal IQ, performance and full scale IQ have negative association with blood lead level $(\mathrm{p}<0.001)$. The findings of the present study are consistent with previous studies(Herbert, 1990; Bellinger, 2004; Bellinger, 2008) ${ }^{20-22}$.

Several previous studies showed different degrees of loss of IQ points for each microgram per deciliter increase in BLL e.g. a 0.87 point decrease in IQ for each microgram per deciliter increase in BLL(Canfield, 2000)23; a 0.99 point decrease in IQ for each microgram per deciliter increase in BLL (Lanphear,2005) ${ }^{15}$. In present study, decrement in verbal IQ, performance and full scale IQ associated with 1 microgram per deciliter increase in blood lead concentration was $0.99,0.86$ and 0.95 respectively.

Traditionally the neuromuscular disorder associatedwith lead poisoning has been purely motor. But after a critical 
review and meta-analysis on NCS in 32 studies on asymptomatic lead workers, Davis and Svendsgaard(1990) ${ }^{24}$ concluded that there were no substantive differences in NCS between the asymptomatic workers and normal controls. This result is consistent with present study findings as no substantive differences were found in NCS between the asymptomatic rise of BLL and normal controls.

Jiann-Horng Yeh $(1995)^{25}$ reported that early conduction abnormalities in lead neuropathy are manifested by prolonged distal latencies rather than a slowing of NCV. In this study no abnormalities were found in distal latency. But all the participants were asymptomatic and BLL of them were not as much elevated compared to their study.

Joel Schwartz $(2001)^{26}$ performed clinical and electrophysiological evaluation in 202 five to nine year-old children living near a lead smelter in Idaho. Blood lead levels ranged from 13 to $97 \mu \mathrm{gm} / \mathrm{dl}$. There was no clinical feature of neuropathy in those children. But asymptomatic increase of BLL was associated with slowing of nerve conduction velocity in motor nerves. In this study, the age group was nearly similar (6 to 12 year). BLL was much lower (3.6-31.9 $\mu \mathrm{gm} / \mathrm{dl}$ ) in the study comparison to previous study. No clinical feature of neuropathy was found in the children; which is similar to other study finding. No difference was found in electrophysiological evaluation; which is contrary to previous study finding. One explanation to this finding is that, BLL of this current study subjects were significantly low.

In a developing country like Bangladesh, lead poisoning seems to be a matter of concern both in occupational and environmental aspects.In this studyhigher blood lead level had a significant negative impact on IQ level of school children and impairs their neuropsychological development. No significant association was found between BLL and neuropathy probably because the BLL of the environmental lead exposed children was not that much raised and the duration of exposure was small to cause neuropathy.

\section{References}

1. Lovei M. Eliminating a silent threat: World Bank support for the global phase out of lead from gasoline. In: Proceedings of International Conference on Lead Poisoning, Bangalore, India, 8-10 February 1999. Bangalore, The George Foundation, 1999:169-80.

2. Khaliquzzman M. Trace element composition of size fractionated airborne particulate matter in urban and rural areas in Bangladesh - report. Dhaka, Accelerator Facilities Division and Chemistry Division, Atomic Energy Centre, 1997.

3. Kaiser R, Henderson AK, Daley WR, Naughton M, Khan MH, Rahman M, et al. Blood Lead Levels of Primary School Children in Dhaka, Bangladesh. Environmental Health Perspectives. 2001;109:563.

4. Rossi E. Low level environmental lead exposure - a continuing challenge. The Clinical biochemist 2008;29:63-70.

5. PEDIATRICS. Copyright (C) 2005 by the American Academy of Pediatrics. 1036 PEDIATRICS Vol. 116 No. 4 October 2005 doi:10.1542/peds.2005-1947.

6. Peripheral neuropathy. Windebank AJ, Dyck PJ, Thomas PK, Griyn JW, WB Sanders, 3rd ed. Philadelphia. 1993:1549-70.

7. Cleveland LM, Minter ML, Cobb KA, Scott AA, German VF. Lead hazards for pregnant women and children: American Journal of Nursing 2008; 108:409.

8. $\mathrm{Hu} \mathrm{H}$, Shih R, Rothenberg S, Schwartz S. The epidemiology of lead toxicity in adults: measuring dose and consideration of other methodological issues. Environmental health perspectives 2007;115:455-62.

9. Seppalainen A-M, Hernberg S. Sensitive technique fordetecting subclinical lead neuropathy. Br Y Ind Med. 1972;29:443-9.

10. Seppalainen AM, Tola S, Hernberg S, Kock B. Subclinicalneuropathy at "safe" levels of lead exposure. Arch EnvironHealth 1975;30: 180-3.

11. Nielsen CJ, Nielsen VK, Kirkby H, Gyntelberg F. Absenceof peripheral neuropathy in long-term leadexposed subjects. ActaNeurolScand 1982;65:241 -7.

12. Triebig G, Weltle D, Valentin H. Investigations on neurotoxicity of chemical substances at the workplace. V. Determination of the motor and sensory nerve conduction velocity in persons occupationally exposed to lead. Int Arch Occup Environ Health 1984;53:189204.

13. Meyer PA, Falk M. A global approach to childhood lead poisoning prevention. International journal of hygiene and environmental health. 2003;206:363-9.

14. Wasserman G A, Liu X, Parvez F, Ahsan H, Levy D, Factor-LitvakP,et al. Water Manganese Exposure and Children's Intellectual Function in Araihazar, Bangladesh.EnvironHealthPerspect 2005;114:124-129

15. Lanphear B, Hornung R, Khoury J, Yolton K, Baghurst $\mathrm{P}$, Bellinger D, et al, Low-level environmental lead exposure and children's intellectual function: an international pooled analysis. Environmental health perspectives. 2005;113:894-9.

16. National Research Council, Measuring Lead Exposure in Infants, Children, and Other Sensitive Populations. Washington, DC: National Academy Press, 2003

17. Schwartz J, Low-level lead exposure and children's IQ: A meta-analysis and search for a threshold. Environ Res.1994;65:42-55.

18. Pocock SJ, Smith M, Baghurst PA 1994 Environmental lead and children's intelligence: a systematic review of the epidemiological evidence. BMJ. 1994;309:1189-1197. 
19. Chen A, Dietrich KN, Ware JH, Radcliffe J, Rogan WJ, IQ and Blood Lead from 2 to 7 Years of Age: Are the Effects in Older Children the Residual of High Blood Lead Concentrations in 2-Year-Olds? Environ Health Perspect.2005;113:597-601.

20. Herbert L. Needleman, Constantine AG 1990, LowLevel Lead Exposure and the IQ of Children A Metaanalysis of Modern Studies. JAMA.1990;263:673-678.

21. BellingerDC, Lead. Pediatrics. 2004;113;1016-22.

22. Bellinger DC, Very low lead exposures and children's neurodevelopment. Current opinion in pediatrics.2008;20:172-7.

23. Canfield RL, Henderson CR, Cory-Slechta DA, Cox C, Jusko TA, and Lanphear BP , Intellectual Impairment in Children with Blood Lead Concentrations below 10 $\mu \mathrm{g}$ per Deciliter. N Engl J Med. 2003;348:1517-26.
24. Davis JM, Svendsgaard DJ. Nerve conduction velocity and lead: a critical review and meta-analysis. In: Advances in neurobehavior toxicology: applications in environmental and occupational health. Chelsea, MI: Lewis, 1990:353-76.

25. Jiann-HorngYeh, Yang-Chyuan Chang, Jung-Der Wang. Combined electroneurographic and electromyographic studies in lead workers. Occupational and Environmental Medicine 1995; 52:415-419.

26. Joel Schwartz, Philip J. Landrigan, Robert G. Feldman, Ellen K. Silbergeld, Edward L. Baker Jr., Ian H. von Lindern. Threshold effect in lead-induced peripheral neuropathy. The Journal of Pediatrics, Volume 112, Issue 1, January 1988, Pages 12-17 J. Neurol. Neurosurg. Psychiatry 2001; 71; 200-204 